\title{
The Analysis of Zakat Accounting Implementation on Amil Zakat Institutions in Bandung
}

\author{
Adeh Ratna Komala \\ Accounting Department \\ Universitas Komputer Indonesia \\ Bandung, Indonesia \\ adeh.ratna@email.unikom.ac.id
}

\begin{abstract}
The purpose of this study is to analyze the implementation of zakat accounting on zakat management organization in Bandung as a form of accountability to the muzakki. Zakat is a financial obligation having social and presenting theological value (deity) which can be the backbone for society economy. The potential of Zakat in Indonesia is enormous though small in realization. Zakat Management Organization is a public institution with its main function to manage the people's funds. The obligation of this organization is to be responsible for all of the people's funds transparently. The form of responsibility especially towards the muzakki is through zakat accounting implementation. The data used in this research were gained by survey i.e. distributing questionnaire towards Zakat Management Organization located in Bandung and registered in Directorate General of Taxation. The data then were analyzed statistically. The method of this research was explanatory to find the basic answer. The result shows that financial report accountability is influenced by zakat accounting implementation.
\end{abstract}

Keywords—zakat accounting, accountability, zakat management organization.

\section{INTRODUCTION}

The majority of Moslem citizens absolutely become chances to maximize zakat potential in Indonesia. According to [1], this zakat potential reached up to IDR 217 trillions in 2016 or equals to $3.4 \%$ of the Gross Domestic Product (GDP) and has been absorbed for about 3.7 trillions. While, [2] stated that profession zakat potential in Bandung reached IDR 1.5 billions per month in 2016 but has been used properly for about IDR400 millions per month.

Based on [3], the huge amount of zakat potential which has not been optimized is caused by the lack of human resources competence and remuneration towards the "amil zakat". Even, [4] stated that problems in reaching up the target of zakat are unavailability of sanctions for muzakki (person who are obliged to pay zakat) who do not perform their obligation, unclear organization structures, lack of human resources competence, and poor information system or network.

[5] stated that zakat management organization is a public institution with its responsibility to manage public funds by collecting, distributing and reporting all the amount of funds to the public transparently. The development of Amil Zakat Agency and Amil Zakat Institution in Indonesia needs to be improved with the process public accountability and transparency by putting forward the motivation of carrying people's trusts [3]. The first challenge for Amil Zakat Agency and institution, according to [6], is in performing the financial report with financial accounting standard. Furthermore, he stated that financial accounting standard for zakat is essential because it can be used as means to present financial transparency as well as improve the quality of financial service to the public.

Intransparent financial report of Zakat Management Organization gives impact of distrust from zakat spender (muzakki) [7]. [4] also stated that zakat is included as public financial domain in which the funds come from the society and has to be reported in transparent way since it will give influence to the level of public trust.

1. The problems described earlier are the necessity of why the research about implementation of zakat accounting and its impact towards accountability of zakat management organization to the public was conducted. According to the description, the writer put forwards the research tittle as "The Analysis of Zakat Accounting Implementation and its Impact towards Accountability of Zakat Management Organization".

\section{METHOD}

The research method used was descriptive and verificative. There are seven out of nineteen amil zakat agencies registered in Directorate Generale of Taxation as agencies receiving the zakat located in Bandung and six out of seven agencies had fulfilled the questionnaire proposed by the writer. They are Rumah Zakat Indonesia, Dompet Peduli Ummat Daarut Tauhid (DPU-DT), Dompet Dhuafa, Pos Keadilan Peduli Ummat (PKPU), Baitul Maal Hidayatullah dan LAZ Muhammadiyah. The distribution of questionnaire was carried out by sending it to the accounting/finance personnel of the agencies which were determined as the sample of this research.The Zakat Management Organization was decided as analysis unit because it is an organization concerning on public funds which has to be responsibly reported.

The method used in collecting the data was survey by using questionnaire distributed by mail and e-mail. The research was conducted in July 2018. Zakat Management organizations that are sampled in this study are 6, namely Rumah Zakat Indonesia, Dompet Peduli Ummat Daarut Tauhid (DPU-DT), Dompet Dhuafa, Pos Keadailan Peduli 
Ummat (PKPU), Baitul Maal Hidayatullah dan LAZ Muhammadiyah. Whilst, the data analysis done through (i) descriptive analysis, i.e. describing the examined variables characteristics in order to support problem solving to gain suggestions operationally; (ii) Structural Equation Model (SEM) to find out the answer of problem formulation and the hypotheses.

\section{RESULTS}

\section{A. Description of Zakat Accounting Implementation Variable (Variable X)}

There were four indicators used to measure the latent variable of zakat accounting i.e.recognition, measurement, presentation and disclosure. The evaluation results from the respondents for those four indicators are presented in the table 1: Evaluation on Zakat Accounting Implementation.

\section{TABLE I. EVALUATION ON ZAKAT ACCOUNTING IMPLEMENTATION}

\begin{tabular}{|c|c|c|c|c|c|c|c|c|c|c|}
\hline \multirow{2}{*}{$\begin{array}{l}\mathbf{N} \\
\mathbf{o}\end{array}$} & \multirow[b]{2}{*}{$\begin{array}{c}\text { Indicat } \\
\text { or }\end{array}$} & \multicolumn{2}{|c|}{$\begin{array}{c}\text { Scor } \\
\text { e } 5 \\
\end{array}$} & \multicolumn{2}{|c|}{$\begin{array}{c}\text { Scor } \\
\text { e } 4\end{array}$} & \multicolumn{5}{|c|}{ Notes } \\
\hline & & $F$ & B & $F$ & $\boldsymbol{B}$ & $\begin{array}{l}\text { Stan } \\
\text { dard } \\
\text { Cred } \\
\text { ence }\end{array}$ & $\begin{array}{c}\text { Resu } \\
\text { lt } \\
\text { Cred } \\
\text { ence }\end{array}$ & $\%$ & $\begin{array}{c}\text { Mea } \\
n \\
\text { Score }\end{array}$ & Criteria \\
\hline 1 & $\begin{array}{l}\text { Recogn } \\
\text { ition }\end{array}$ & 5 & $\begin{array}{l}2 \\
5\end{array}$ & 5 & $\begin{array}{l}2 \\
0 \\
\end{array}$ & 50 & 45 & $\begin{array}{l}9 \\
0\end{array}$ & 4,50 & $\begin{array}{l}\text { Very } \\
\text { Good }\end{array}$ \\
\hline 2 & $\begin{array}{c}\text { Measur } \\
\text { ement }\end{array}$ & 4 & $\begin{array}{l}2 \\
0\end{array}$ & 6 & $\begin{array}{l}2 \\
4 \\
\end{array}$ & 50 & 44 & $\begin{array}{l}8 \\
8 \\
\end{array}$ & 4,40 & $\begin{array}{l}\text { Very } \\
\text { Good }\end{array}$ \\
\hline 3 & $\begin{array}{c}\text { Present } \\
\text { ation }\end{array}$ & 5 & $\begin{array}{l}2 \\
5 \\
\end{array}$ & 5 & $\begin{array}{l}2 \\
0 \\
\end{array}$ & 50 & 45 & $\begin{array}{l}9 \\
0 \\
\end{array}$ & 4,50 & $\begin{array}{l}\text { Very } \\
\text { Good }\end{array}$ \\
\hline 4 & $\begin{array}{l}\text { Disclos } \\
\text { ure }\end{array}$ & 4 & $\begin{array}{l}2 \\
0 \\
\end{array}$ & 6 & $\begin{array}{l}2 \\
4 \\
\end{array}$ & 50 & 44 & $\begin{array}{l}8 \\
8 \\
\end{array}$ & 4,40 & $\begin{array}{l}\text { Very } \\
\text { Good }\end{array}$ \\
\hline \multicolumn{6}{|c|}{$\begin{array}{l}\text { Zakat Accounting } \\
\text { Implementation (X) }\end{array}$} & 200 & 178 & $\begin{array}{l}8 \\
9\end{array}$ & 4,45 & $\begin{array}{l}\text { Very } \\
\text { Good }\end{array}$ \\
\hline
\end{tabular}

Source : Questionaire Processing Result, 2017

\section{B. Description of Financial Report Accountability Variable (Variable $Y$ )}

There were five indicator used to measure the latent accountability variable i.e.: 1) legal and integrity accountability, 2) managerial accountability, 3) program accountability, 4) policy accountability, and 5) financial accountability. The result of respondents evaluation for those indicators are shown in the table 2: Evaluation on Accountability.

TABLE II. EVALUATION ON ACCOUNTABILITY

\begin{tabular}{|c|c|c|c|c|c|c|c|c|c|c|}
\hline \multirow{2}{*}{$\begin{array}{l}\mathbf{N} \\
\mathbf{o}\end{array}$} & \multirow[b]{2}{*}{$\begin{array}{l}\text { Indic } \\
\text { ator }\end{array}$} & \multicolumn{2}{|c|}{$\begin{array}{l}\text { Sco } \\
\text { re } 5\end{array}$} & \multicolumn{2}{|c|}{$\begin{array}{c}\text { Score } \\
4 \\
\end{array}$} & \multicolumn{5}{|c|}{ Caption } \\
\hline & & $F$ & $\boldsymbol{B}$ & $F$ & B & $\begin{array}{c}\text { Standar } \\
d \\
\text { Creden } \\
\text { ce } \\
\end{array}$ & $\begin{array}{l}\text { Result } \\
\text { Creden } \\
\text { ce }\end{array}$ & $\%$ & $\begin{array}{c}\text { Mea } \\
n \\
\text { Score }\end{array}$ & $\begin{array}{c}\text { Crite } \\
\text { ria }\end{array}$ \\
\hline 1 & $\begin{array}{l}\text { Legal } \\
\text { and } \\
\text { Integr } \\
\text { ity } \\
\end{array}$ & 4 & $\begin{array}{l}2 \\
0\end{array}$ & 6 & 24 & 50 & 44 & 88 & 4,40 & $\begin{array}{c}\text { Very } \\
\text { Goo } \\
\text { d }\end{array}$ \\
\hline 2 & $\begin{array}{l}\text { Mana } \\
\text { gerial }\end{array}$ & 6 & $\begin{array}{l}3 \\
0\end{array}$ & 4 & 16 & 50 & 46 & 92 & 4,60 & $\begin{array}{c}\text { Very } \\
\text { Goo } \\
\text { d } \\
\end{array}$ \\
\hline 3 & $\begin{array}{c}\text { Progr } \\
\text { am }\end{array}$ & 4 & $\begin{array}{l}2 \\
0\end{array}$ & 6 & 24 & 50 & 44 & 88 & 4,40 & $\begin{array}{c}\text { Very } \\
\text { Goo } \\
\text { d } \\
\end{array}$ \\
\hline
\end{tabular}

\begin{tabular}{|c|c|c|c|c|c|c|c|c|c|c|}
4 & $\begin{array}{c}\text { Polic } \\
\mathrm{y}\end{array}$ & 8 & 4 & 2 & 8 & 50 & 48 & 96 & 4,80 & $\begin{array}{c}\text { Very } \\
\text { Goo } \\
\mathrm{d}\end{array}$ \\
\hline 5 & $\begin{array}{c}\text { Finan } \\
\text { cial }\end{array}$ & 5 & 2 & 5 & 20 & 50 & 45 & 90 & 4,50 & $\begin{array}{c}\text { Very } \\
\text { Goo } \\
\mathrm{d}\end{array}$ \\
\hline \\
Accountability (Y) & $\mathbf{2 5 0}$ & $\mathbf{2 2 7}$ & $\mathbf{9 1}$ & $\mathbf{4 , 5 4}$ & $\begin{array}{c}\text { Very } \\
\text { Goo } \\
\mathbf{d}\end{array}$ \\
\hline
\end{tabular}

Source : Questionaire Processing Result, 2017

\section{The Influence of Zakat Accounting Implementation towards the Financial Report Accountability}

By using SmartPLS, it was gained that SEM analysis result is as picture 2: Coefficient Values of Measurement and Structural Models and picture 3: Statistics Values of tCounted

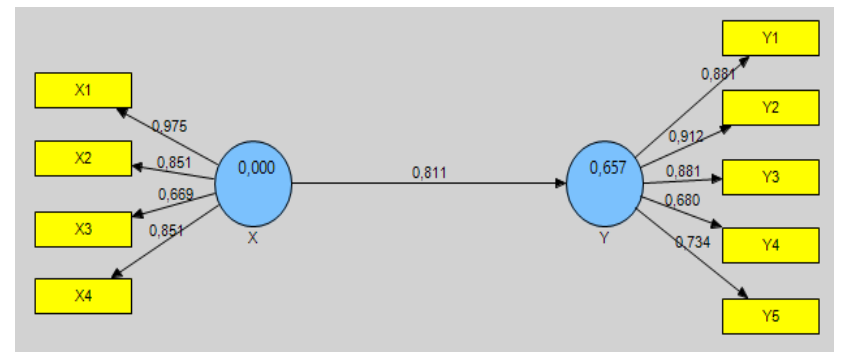

Fig.1 Coefficient Values of Measurement and Structural Models

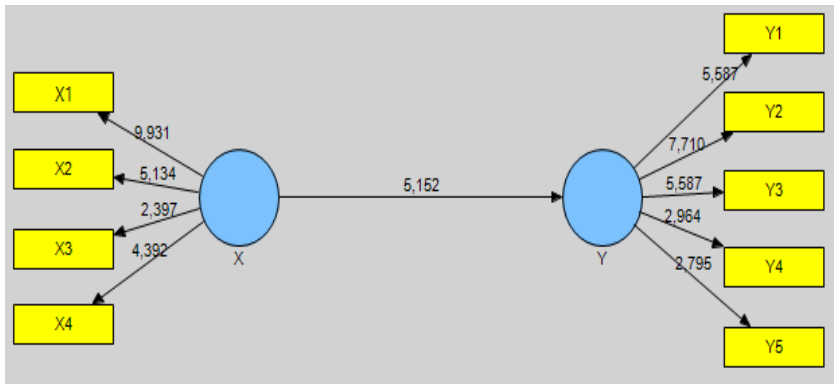

Fig 2. Statistics Values of t-Counted

Notes:

$\mathrm{X}=$ Zakat Accounting Implementation

$\mathrm{Y} \quad=$ Accountability

According to the values gained and the result analysis of SEMPLS, it was founded that the calculations of contribution percentage/influence of the exogenous latent variable towards the endogenous latent variable as table 3: Contribution of the Infljuence of Zakat Accounitng Impelementation toward Accountability.

TABLE III. CONTRIBUTION OF THE INFLUENCE OF ZAKAT ACCOUNTING IMPLEMENTATION TOWARDS ACCOUNTABILITY

\begin{tabular}{|c|c|c|}
\hline Influence & $\begin{array}{c}\text { Structural Path } \\
\text { Coefficient }\end{array}$ & $\begin{array}{c}\text { Influence } \\
\text { Percentage (KD) }\end{array}$ \\
\hline $\mathrm{X} \rightarrow \mathrm{Y}$ & 0,811 & $65,77 \%$ \\
\hline
\end{tabular}

Based on the table, it is known that the value of path coefficient is 0.811 so that it can be found out that the amount of contribution of the influence of Zakat Accounting Implementation towards the accountability is as much as $65.77 \%$.

\section{Hypotheses Testing}

Hypotheses 
$\mathrm{H}_{0} \quad$ : Zakat Accounting Implementation does not give significant influence towards Accountability

$\mathrm{H}_{1} \quad$ : Accounting Implementation gives significant influence towards Accountability

$\alpha=0,05$

By the result of bootstraping SmartPLS, the $\mathrm{t}$-counted for the variable of Zakat Accounting Implementation towards Accountability equals to 5.512. this value is more than the critical point 1.96 and thus it can be concluded that the testing result rejects $\mathrm{H}_{0}$ and accepts $\mathrm{H}_{1}$, meaning that Zakat Accounting Implementation is proven to give significant influence towards Accountability.

\section{DISCUSSION}

According to the result of the research, it is described that the zakat management organization has generally implemented the zakat accounting excellently in which the score reaches $89 \%$ or 4.45 for the mean score. This shows that in presenting the financial report, the organization performs ideal score (very appropriate) to the standard of Financial Accounting Ascociation (PSAK) No.109 concerning about zakat and infaq/shadaqah accounting as the harmonization of PSAK and IFRS. Previously, the zakat management organization presented their financial report based on PSAK 45 about nonprofit organization financial report. Ideal score was not ideally gained since the gap was $11 \%$ meaning that the organization had to do sorts of efforts to reach the ideal score.

Regarding the financial report accountability, the research resulted "very good" criteria with $91 \%$ as the score and 4.54 as the mean score. This shows that accountability of zakat management organization covers legal and integrity accountability, managerial accountability, program accountability, policy accountability, and financial accountability with all indicators performing ideal scores. Consequently, it is the assignment for the zakat management organization to perform their responsibility for the operation to the concerned-parties especially the muzakki.

The nonprofit organization characteristics differ from the profit one, therefore the accountability is an interesting topic to be discussed. The health of an organization can be seen in its management which performs transparency, accountability, flexible bureaucracy, and quality standard possession as well as clarity in target and quality objectives [7].

The research shows that the influence of zakat accounting implementation towards financial report accountability as much as $67.77 \%$. This means that there are another factors influencing the financial report. Presenting transparent and relevant financial report is absolutely the form of accountability.

The zakat management organization need to maintain public's trust especially the muzakki (zakat payer) in running its operational i.e.receiving zakat/donation whether it is in the form of funds or goods by presenting financial report based on PSAK 109.Transparency is the control from the public for evaluating the organization. The financial report has to be published regularly to the muzakki as the form of its accountability to the users (muzakki) and the God the Almighty.

\section{CONCLUSIONS}

Based on the problem formulation and hypotheses mentioned earlier, it is concluded that Zakat Accounting Implementation gives significant influence towards financial report accountability. There are another factors giving impact to the accountability of a financial report which need to be furtherly examined/researched. The implementation of zakat accounting in zakat management organization is the form of its accountability in managing public's funds which is presented in financial report. Each cent of funds has to be accounted for the muzakki and to God the Almighty.

\section{References}

[1] Junaidi Mulkan. 2016. Pemerintah Sebut Potensi Zakat di Indonesai Rp 217 Triliun Terhimpun Hanya Rp 37 Triliun. melalui.http://bali.tribunnews.com/2016/08/31/ pemerintah-sebutpotensi-zakat-di-indonesia-rp-217-triliun-terhimpun-hanya-rp-37triliun

[2] Ridwan Kamil. 2017. Tingkatkan Zakat Profesi, Kang Emil Akan Gunakan Smart City. melalui http://forumzakat.org/tingkatkanzakat-profesi-kang-emil-akan-gunakan-smart-city/

[3] Ahmad Juwaini. 2011. Strategi Pengembangan SDM Zakat Indonesia. FOZ (Forum Zakat).

[4] Didin Hafidhuddin. 2017. Penyaluran Zakat itu Harus Bermartabat. melalui ttps://www.eramuslim.com/berita/bincang/didin-hafidhuddinpenyaluran-zakat-itu-harus-bermartabat.htm\#.WLJKQ_LhPIV

[5] Nana Minarti. 2012. IMZ Award dan Sinergi Zakat Dunia. Posted in IMZ Award

[6] Pistaza. 2011. Berlakunya PSAK Zakat No. 109. Melalui https://pistaza.wordpress.com /2011/10/08/berlakunya-psak-zakatno-109/

[7] Nikmatuniayah dan Marliyati. 2015. Akuntabilitas Laporan Keuangan Lembaga Amil Zakat di Kota Semarang. Mimbar Vol. 31 No. 2 485-494 